\title{
Families of Centenarians
}

\author{
Alda Britto da Motta \\ Department of Sociology, Faculty of Philosophy and Human Sciences, Federal University of Bahia, \\ Salvador/BA, Brazil
}

\begin{abstract}
Multigenerational families, shaped by fundamental phenomena of today's world like human longevity and the restructuring of production, unite generational actors in new socio-affective relationships. Firstly, and contrary to the somewhat stereotyped contemporary image, uncommon figures such as the centenarians are generally lucid and in good or reasonable bodily health. Whatever the state of their physical health, though, they need affection like anyone else, as well as practical day-to-day support. Their children may come together to enable this care, but generally the support is provided by a daughter, fulfilling the classic female social role of caregiver. These daughters, whether elderly themselves or mature, represent the pivotal or intermediary generation, the second great player in these multigenerational families, who also provide support to the younger generations, including children and grandchildren. Such support extends to financial assistance, required by those mainly younger family members who are unemployed or only precariously employed, as well as by those who experience new family situations, such as separations and returning to home, generally the maternal home. This is the panorama that I propose to analyze, based on research data.
\end{abstract}

Keywords: Centenarians, Multigenerational families, Gender, Care.

\section{Resumo}

Famílias multigeracionais, moldadas por fenômenos básicos da contemporaneidade, a longevidade e a reestruturação produtiva, abrigam personagens geracionais que são novos enquanto relações afetivo-sociais. Em primeiro lugar, os centenários, figuras incomuns - diferentemente da imagem meio preconceituosa vigente, são em maioria lúcidos e em boa ou razoável condição corporal. Entretanto, por maior que seja a sua vitalidade, demandam apoios - afetivos, como todos - mas também materiais, cotidianos. Os filhos enfeixam essa possibilidade de cuidado, porém geralmente esse lugar de apoio é preenchido por uma filha, cumprindo o papel social clássico, feminino, de cuidadora. É a representante da geração pivô, ou intermediária - segunda grande personagem geracional nessa família; idosa ou madura, é apoio também das gerações mais jovens, filhos e netos. Apoio que se estende ao âmbito financeiro, demandado pelos que estão desempregados ou precariamente empregados. Abrangendo ainda os que vivem novos padrões de família, com as separações e retornos à casa, geralmente materna. Aí já se encontram principalmente os jovens. É o panorama que proponho analisar, com base em dados de pesquisa.

Palavras - Chave: Centenários, Famílias multigeracionais, Gênero, Cuidado. 


\title{
Families of Centenarians
}

\author{
Alda Britto da Motta
}

\section{Introduction}

In a society whose population is increasingly long-lived, the number of living generations is inevitably expanding. This multiplication of generations also exists within the elderly population in the form of various age groups, designated in research studies as 'young' aged, the older elderly, and centenarians. One outcome of this simultaneity are multigenerational families, a group of new or transformed relationships, and new generational actors. At the same time, this shift has led to an overlapping of roles within the family and of the kinship situations for each individual.

This is a world in movement and change where the characteristics traditionally associated with 'aging,' including 'natural' health problems, are now delayed until later and later in life (Fernandes 2001). At the same time, the less elderly are becoming increasingly 'youthful' (Britto da Motta 2012).

These changes also vary in accordance with the bio-social conditions of each elderly person, depending in particular on their gender, class and race. Indeed these different phases of old age may reflect diverse social and corporal conditions and lifestyles (not forgetting individual differences, of course). As well as being born at distinct social moments and, consequently, so that their class, gender and generation habitus were formed in different social and temporal conditions (Bourdieu 1990, Britto da Motta 1999), each individual possesses varying amounts of accumulated life experience and corporal and affective/emotional practices and expenditures that combine to influence the present. Consequently they live a highly relativized actuality, just as Mannheim (1928: 124) observed: the 'same time' is not the same for all: "everyone coexists with people of the same and different ages [...] but for each person the 'same time' is a different time..."

Moreover, as recent studies have just begun to show, the time period when contemporary elderly generations were being formed was and is becoming more and more diversified. So too their life experiences and the length of the time already lived. But it is equally important to accentuate the unequal power relations involved between the generations in each individual's social and everyday trajectory, beginning with family relations. The family, always the primary space for shaping gender and generational relations (Britto da Motta 2003), today exhibits the peculiarity of various simultaneous generations and in a more long-lasting way than any other epoch in history - to such an extent that we now encounter families with up to four or five coexistent generations, and domestic units where three or more generations cohabit. And very often two of these generations are elderly.

So how are these different generations experiencing, through their everyday relations, events happening in the wider social context? And who precisely are these elderly people?

Leading the way are the young elderly. This demographic group corresponds to what became known in the 1960s, first in Europe but soon globally, as the 'third age' (Lenoir 1979). The period in question saw an increasing participation of the middle class in the labor market, a rise in their corresponding level of income from pensions, and, of course, more time and resources available for leisure. At the same time, this emerging social context became targeted by promoters of diverse activities, providers of consumer goods and services, and the media. All of which, as Ariès (1983) would point out with due acerbity, involved activities and organizations that effectively corralled the elderly into virtual ghettos, designed merely as 
means to put old people's money back into circulation. In this way, the elderly became the recipients of an endless array of socializing programs, such as clubs, groups, and 'universities' for the 'third age,' and various enticements to consumerism, like group 'fun' tours, soon followed by 'special anti-aging' cosmetics, and 'suitably adapted' residences, not to mention the diverse healthcare packages.

These younger elderlies have also proven to be one of the most attractive and accessible subjects for scientific research, though even more so for the media, whose frequent and widely divulged reports have been directly responsible for a (now not so new) social image of the elderly citizen as dynamic, happy and healthy, transforming the image of the 'poor old people,' retired from almost all aspects of active life, that belonged to a not so distant and still sometimes persistent past. They also represent the historically uniqueness, particularly in Brazil, of the longer time spent in the labor market and, in particular, the growing return to work, albeit mostly in an informal capacity (Britto da Motta 2001, Peixoto 2004, Souza 2009). At the same time, along with the older elderly segment, they are beneficiaries of social security payments, such as retirement plans and pensions. Though in most cases meager, this regular income provides elderly people with financial stability. Importantly this in turn allows them the chance to renew relations with their families and contribute to them, especially young people affected by the precarious employment and structural unemployment of the present.

The older elderly. This group is sometimes tentatively referred to as the 'fourth age.' I say tentatively since there is clearly some difficulty in approaching and thus denominating those with a supposedly less attractive, more 'spent' appearance, who are more 'removed' and apparently less sociable. They tend to be less present at parties, clubs and festivals, and in public spaces more generally, as I have already had the opportunity to analyze (Britto da Motta 2004). Consequently they cultivate a more restricted and traditional sociability, visiting and celebrating with old friends and family members, as well as maintaining their religious practices.

Yet despite those of a more advanced age typically being left out of an enticing social calendar connected to 'young' lifestyles (Lins de Barros 2006) and events, they - just like those of the 'third age' - are being targeted by an increasingly advanced preventative medicine, informed (themselves or their families) by an ever-expanding system of communication. As a result, octogenarians and nonagenarians are enjoying increased health and sociability, as already well-established among the 'third age' sector. They are also gradually frequenting social centers and joining assistance and cultural groups very similar to those adopted by the younger elderly.

The same phenomenon is starting to occur among centenarians. Some of those interviewed during the most recent phase of my research participated regularly in groups. In addition to reflecting better health, this change illustrates the aforementioned phenomenon of patterns of physical and existential practices being temporally dislocated into the future. This shift is already registered in everyday speech through expressions like "eighty years old today is like being sixty or seventy in the past." The phenomenon is especially true in relation to women.

However the market's hold over the elderly is still much less intense than over 'young' people, reflected too in their lower visibility in the media and social networks. And without the same stimulation from news reports and other information sources, scientific research has likewise tended to overlook or neglect this group, almost to the same degree as the State.

It is important to remember, though, that much of this 'fourth' age sector constitutes an intermediary or pivotal generation, hierarchically located between the centenarians and the younger family generations, and made more important by the support that they provide - both in terms of care and financially - to other generations (Britto da Motta 2012, Attias-Donfut 1995). 
The centenarians. This is the smallest demographic contingent, representing less than $1 \%$ of the Brazilian population, though also expanding as people generally live longer. The group arouses a certain curiosity due to their advanced age and how they managed to reach it. Even so, public interest and to some extent market interest in this age group remains limited except in the healthcare sector.

\section{Centenarians}

According to Brazil's census statistics for 1991, there were 13,865 centenarians in the country, made up of 9,208 women (66.4\%) and 4,657 men (33.6\%). In the 2010 census, this figure had almost doubled to 24,236 , while the number of women quadrupled in relation to men: 19,989 women $(82.48 \%)$ compared to 4,247 men $(17.52 \%)$.

In Bahia, the Brazilian state with the largest contingent of centenarians, there were 3,578 according to the 2010 Census, with 2,442 women (68.25\%) and 1,136 men (31.75\%), 70\% living in urban areas. Overall they share a number of characteristics already well-observed among other elderly sectors of the population, such as the very clear predominance of women with the female contingent increasing as the population ages. This in turn defined many of the fundamental characteristics of the demographic: predominantly widows, a large number of single women (around 16\%) and low levels of schooling (reflecting the many restrictions on women's formal education for much of the twentieth century).

The literature on this elderly sector, very limited, is generally concentrated in the healthcare area. Material in the social sciences is even more scarce. Looking further back in time, we can cite the short but pioneering chapter by Simone de Beauvoir in La Vieillesse (1970). It The work is especially interesting since it quotes findings from studies conducted in France and the United States that already revealed the exceptional state of health and energy of this demographic sector - identical to characteristics that I have been encountering today in my own research.

At present, studies and research are being undertaken on 'advanced aging' and 'hyper-centenarians' (people aged over 110 years) by a number of teams at some European and US universities, in the main, accompanied by periodic meetings of the International Centenarian Consortium, generally preceding international congresses in the areas of Gerontology and Geriatrics, which set much of the tone of the works presented. There is now a widespread competitive interest in determining the identity and location of the oldest person in the world.

In Brazil, studies are also confined almost exclusively to the healthcare area, and frequently limit their findings to demographic and statistical data. The equally important social context, ways of life and the subjective everyday experiences are still not sufficiently covered, however. In the field of the social sciences, there is just the brief introduction by Ana Amélia Camarano (1999) to the book Muito Além dos 60 [Far Beyond the Sixties] and prospective studies by Britto da Motta (2006). The latter research was developed in two phases: starting out with general research data ${ }^{1}$ on the elderly and their family relations, in which the very old already stood out, followed by specific research on the ways of life of centenarians and the

\footnotetext{
1 Projects: "The older elderly"; "Relations between generations: parents and elderly children" and "Gender and generational relations: parents, children and grandchildren.” Financed by CNPQ (PQ Scholarships), PIBIC and PIBIC/FAPESB (IC Scholarships). Students who participated in various phases: Patrícia Schramm Andrade, Carla Pellegrino, Ulisses Oliveira Amorim, Zilmar Alverita de Silva, Fabiana de Santana Medeiros, Hugo Lessa Gama, Carolina Santana de Souza and Jeane Rangel.
} 
generations supporting them, analyzed in various articles (Britto da Motta 2010, 2012). ${ }^{2}$ The remaining literature consists of diverse news items or reports in magazines and newspapers on the demographic growth of the centenarian sector, or on the birthdays of "surprisingly' lucid and often healthy individuals belonging to this age group.

There has also been a recent trend of attempting to determine the exact age and geographic location of very elderly people in order to claim not just social distinctiveness, but a place in the Guinness Book of Records. Examples have been reported frequently in newspapers and on the internet, including the case of the Bahian woman, Dona Maria Isídia, 124 years old, whose inclusion in the Guinness Book of Records occurred as a direct result of a claim made by her family (www.gl.globo.com).

In any case, the public acknowledgment of an elderly person's exceptional age is clearly complimentary to the family. Also in Bahia, our team is currently accompanying Dona Eurides, 120 years old, who has featured in a news report (i.bahia, 26/3/2015) precisely as another potential candidate for the world's oldest person. However, lacking any close living relatives and residing in a charity-run home, she appears unconcerned with providing additional proof for her claim, though she remains extremely lucid and content: she loves being photographed.

In most of the material available on centenarians, ranging from Simone de Beauvoir's work to news reports, we can detect two perennial themes. First the affirmation of their good physical and mental health, frequently better than that of their own elderly children. And second, an ever-present curiosity, mixed with perplexity, concerning the 'achievement' of reaching 100 years of age, or the 'secret' of such extraordinary longevity. Medical scientists are encouraged to research the possible origin of this unexpected health and resilience, while in the social area every centenarian observed or interviewed is probed to reveal 'their' secret - always in this sense of a mystery to be revealed. Today more numerous and visible in the media, they are asked about the 'secret' of their group. One example is the extensive cover story by the Brazilian magazine Época (2006). The magazine managed the feat of listing different 'secrets' for each of the four groups of centenarians living in the Brazilian cities identified by the United Nations Development Program (UNDP) as having the highest life expectancy and proportion of elderly people in the local population.

The different secrets 'revealed' or presumed to exist were: continuing to work; practicing sports; maintaining an active social life; and, having a healthy diet and 'habits.' These more or less match the recommendations of gerontologists published in all the recognized or disguised self-help manuals containing advice on reaching old age with 'quality of life' or 'successful aging...' But not all elderly people are so 'well-behaved.' It is not uncommon for an interviewee to declare that they do not engage in any physical activity or follow an 'adequate' diet, but who are doing just fine at one hundred years old (Britto da Motta 2006). This is the case of Dona Julieta, 106, a Northeastern woman from the State of Paraíba, who very candidly declared: “I eat everything. Beans, prawns, lobster, pork; whatever's put before me, I eat." She also revealed that she never engages in physical activity aside from domestic chores. And she added: "I'm not a total party animal, but I've always liked a party."

Overlooking this frequent 'bad behavior' of the 'senior citizens,' however, they continue to be asked about their 'secrets' in the belief that they can provide us with solutions: extending the course of life by leaning from their example while, contradictorily, distancing ourselves from anything deemed not to be 'youthful.' We want to live for a long time, but without becoming 'old.'

2 Project "Generational roles in the contemporary family: centenarians and pivots"; also supported by PQ and PIBIC/FAPESB scholarships and the participation of students: Clarissa Paranhos Guedes, Elaine de Carvalho Lima, Liv Lobo and Iracema Sousa de Medeiros Costa. 
In the still relatively exceptional case of living to more than one hundred years old, especially while remaining healthy and with a lust for life, curiosity filled with desire and a fearful fascination (the vague dread that we always have of the elderly, "closer to death") elicits this contradictory but persistent question about the 'secret'. Whose revelation - never satisfactory - can lead at times to unexpected reactions: in the end, it is not what we want.

\section{The research}

Over the course of three research projects with elderly people in Bahia, spanning from 2000 to 2007 and involving a total of 104 interviewees, I identified twenty centenarians: fifteen women and five men. Attractive personalities with unfamiliar characteristics, I began to concentrate on them. All were interviewed and recorded, the circumstances of the encounter documented in a field diary and sometimes with photographs. The majority were accompanied for a long time (some until their death) in parallel with the development of new projects exploring the relations between family generations. Most of the families studied were precisely those with these centenarians among their members.

Consequently the centenarians became the main focus of the later projects, though these have also always included the intermediary (pivotal) generations and other family members. Over time I identified a number of common characteristics among them:

Analyzing levels of education, work and income, we can determine that their 'selection' is not linked to class privilege: the majority are of modest means. However, the influence of sex/gender on a long life seems consistent: the majority are women. All of the interviewees possessed their own income, though the level varied considerably and in most cases was low. Frequently their income would be supplemented by some kind of support from their children, especially daughters.

The physical condition of the elderly individuals varied, but even those with health problems, when they felt emotionally content, very often declared that their health was good and that they felt well. Their outlook was generally upbeat most of the time. Complaints existed, but also a sense of tranquility and good humor. They clearly liked living.

Even Dona Etelvina, 124 years of age, the oldest and the most affected by disabilities among our interviewees, was no exception. Able to see very little and moving about only with difficulty, she too chatted, smiled, and told stories, and was described by her 61-year old granddaughter with whom she lived as the "joy of the house."

Afro-Brazilian, her white hair tied back, she was always in good spirits and talkative, despite requiring some effort to be understood owing to a lack of teeth. Her hearing was good, though. She spoke about her difficulties moving around, pointing out the distance from her bedroom to the front room: "Halfway I stop and have a little rest." Despite these difficulties, her granddaughter told us that she insists on showering unassisted.

She tells of the premature loss, at 42 years old, of her only daughter (among the five children who she managed to raise) and the longing that she felt for her other granddaughter, aged 70 , who had been raised by her and was now sick: she wanted to be living in her home. She spoke in detail about the long years of agricultural work: "Hoeing, clearing sugar cane, driving mules, there was no work I didn't do in the fields. I worked so hard that I still feel tired today. But the government doesn't send me anything." She complains about her physical limitations in the present: "I can't even sweep the house I live in!" 'I don't do anything, I just sit around daydreaming. When the food arrives, I eat and remain sat there quietly. I go to bed early...I spend the whole day sat down." 
She recalls: "I never missed a Church mass, I loved going... It was in Santo Amaro" (the rural area where she was born and lived for many years). "I never missed a Christmas party either, no way!" She returned to bemoaning the present: "I don't do anything. (Stretching...) I want to do things and I can't. When I was a girl, I did whatever I wanted. Now, I want to do things, but I can't.” When her granddaughter needs to go out, she describes what happens: "I stay alone with my hand resting on my chin." This matches the photo taken on her last birthday and published in a newspaper report (Oliveira 2002). When speaking about her aging process, she always referred to the constant work: "My body became weaker and weaker. The administrator said: why don't you go home, Dona Etelvina?" She did finally leave work - at the age of 84 .

A lifetime's arduous work on the plantation left her with just a meagre minimum wage. "I receive a pittance; no one helps me.” Dona Etelvina has 5 grandchildren, 26 great-grandchildren, 39 great-greatgrandchildren, and 4 great-great-great-grandchildren: "Ah! If all of them were working to put food on my table!" In an interview with the newspaper during the same period, she compared the labor situation when she was young with the chances available today: "In those days we worked to eat. Today even those who do work can't earn enough to eat" (A Tarde, July 2002). She described her work: "Hoeing, cutting sugar cane and loading wagons. When the time came to cut the cane, the work would continue non-stop until it was done. It was a large sugar mill." The work was demanding: "When I became a widow I stayed at home crying, until the day I had to go out to work. When I worked, I forgot; but now I no longer remember, I'm old."

She complained about the difficulties: "I no longer have my good health. Everywhere aches (...) I can't do anything. What do I matter today?!" Even so, she said that she had a love of life and wished to live longer: "I just don't want to be a burden to others."

Over the course of our research, some of the centenarians passed away, almost invariably without any lengthy period of illness. This was the case of Dona Etelvina, who we visited just once and who died soon after from a stroke. The same occurred with the deaths of other centenarians involved in our research, four of whom comprised the longest accompanied, much admired and cherished by us, and who died in recent years.

The oldest of this group was Seu Anísio. 108 years old at the time of the first interview, a gem of vitality and charm. I accompanied his life trajectory until he was almost 117 years old, when he died in 2010. The son of farmers, he worked as a mason and became a well-known site foreman in Riachão do Jacuípe in rural Bahia. He played in the city's philharmonic and was very popular. Calm and good natured, he enchanted those he met. At the party for his $115^{\text {th }}$ birthday, one of the most lively that I went to, he was especially talkative. At one point he went into the house to look for a photo of the philharmonic group to show to a friend. The photo was passed around among those nearby while he told stories about some of those companions, all of them already dead. He smiled contagiously at the thought of some of them and enchanted a young female guest who, sat by his side, listened to him smiling without missing a single word. She was so enchanted that when called to leave, she hesitated to go.

Seu Anísio was Afro-Brazilian, tall, calm and attentive, with a naturally elegant bearing and always neatly dressed. His health only deteriorated well after he had reached one hundred when he became slightly deaf, but still managing to communicate well. His legs lost some of their strength and in the street he used a walking stick. He was twice widowed and had 15 children, some of the older ones having already passed away. He once remarked about one of them: "People say that he is older than me." Talking about age and marriage, he said: "I'd like to be eighty still and marry again." He also liked to joke about the possibility of still "meeting a pretty young woman" one day...

He possessed an excellent memory, reflected in the impressive precision with which he recalled facts, including dates. As he told me in our first interview: "I arrived from Riachão on the $8^{\text {th }}$ of August, 1961. 
I arrived here in Salvador. I came to this house, in 64." From there he went on to describe how he was owner of a house, located in the Saúde district, where he lived with a housekeeper responsible for domestic chores. He was responsible for the household expenses and explained how he liked to live alone. The children helped, but not regularly: "Every now and then, one gave me something, another something else."

Two daughters lived in the neighborhood, one of whom was his main caregiver. "Anísia takes me everywhere I wish." At home he hated staying still: "I do everything I can (...) I fix one thing, I fix another." He never stayed at home alone since when the housekeeper was out, he would go to his daughter's house. Regarding his relatives, he remarked "I get along well with all of them." He kept in touch by telephone.

He had few close friends since most of his companions had already died: "That's the price of growing old: we lose the people from our youth." He admitted: "I get the urge to visit other people's homes to chat, but the families go to work, the husbands are out, the wives are out. On Sundays they head to the beach. Where would I go? So I stay at home." Sometimes he received visits and was featured in various newspaper and television reports.

Seu Anísio's birthday commemorations were neighborhood events, mobilizing a small crowd of children, grandchildren and other relatives (even young infants would go, always to be photographed with him at some point), as well as friends and admirers from Salvador, and others who came from inland Bahia. A mass was always held in the neighborhood church, followed by dinner at his home. One of the constant attendees, year in and year out, was a friend whose birth certificate he had witnessed in the 'interior.' He proudly proclaimed this fact. The last time I saw him, he was much 'older' and less steady on his legs than Seu Anísio.

Despite his perennial good humor, he did not think it was good to be old, "because the children are the ones in charge, I'm not in charge of anything anymore. If I try to do something, they say: 'Don't do that, do this.' That's why I think it's bad, but life goes on."

In the case of Dona Januária, the desire to meet her was inspired by seeing her portrait in a newspaper report, which showed her smiling broadly, hugging a guitar. In April 2002, at 108 years of age, the first interview took place, where she marvelously declared: "I feel very well and sing in verse and prose." She really did play the guitar at the time. She had made a recording, and was starting to write a book of memoirs, which was released in May 2004 at a party celebrating her $110^{\text {th }}$ birthday. At her $112^{\text {th }}$ birthday celebration, the last that I intended, as always marked by a festive mass, she was merrily chatting and engaging with the guests.

In an earlier and somewhat contradictory interview she had complained about old age, because despite her good memory (and being a teller of stories) her body limited her activities: she used a wheelchair, her voice was hoarse, she had no appetite, and she found it difficult to read ("the letters get mixed up") or write ("the letters don't stay in a straight line" she complained). Her fingers also hurt when she played the guitar.

Pale-skinned, charming and always smiling, in contrast to the complaints. Already a widow for many years, she had never worked outside the home, but, as she emphasized, "I worked at home, a lot of work, because of the nine children!" She received a pension worth the minimum wage, supplemented by her daughters. Her three male children had already passed away. She lived with a younger daughter who took great care of her. "She's responsible for everything about my life here. I was a mother, now I'm a daughter." (Laughing). "She's the head of the household, she's in charge, she sorts things out."

During her husband's illness and after his death she received the invaluable support of her older son, who she spoke of fondly and whose death she lamented to the point of declaring: "For me the world died, I no longer feel joy for anything." Despite her daughter's constant care and the phone calls and weekend visits of the other daughters (aged between 72 and 84 years old) she said that she felt alone. Though she also 
received care and attention from the housekeeper, she complained whenever her daughter went out: "Then I feel alone, you know? I feel it, because she needs to go out and the girl spends all her time working inside the house and she's very quiet. She doesn't even sing!" Dona Januária said that to pass the time "I always have to invent something." "I'm only happy when there are people around, my children, my friends."

Despite the complaints, she said that she had many good friendships: "When it's my birthday, everyone comes." Her children and friends arrange the party and she receives many guests.

She commented on the relationship with her family: "It's good, great even." Not only her children but her grandchildren too would always come to visit her, and when their children were born, they would take them to meet their grandmother: "Some of them take a photo of me with the children". She rarely left the house: "I'm hard work because you have to take the wheelchair out and put it in the car, it's a real bother." As a result she would often decline to go out.

At home, she mainly stayed in her bedroom. She said that she wanted to work, not to make money, but just to do "anything that the others could do but that I can't." Resigned, she recognized her health problems were related to 'old age,' as she put it, and concluded: "This is what I'm like and there's nothing I can do about it."

Accompanying and observing the ways of life of the centenarians was highly revealing in terms of the family relationships of elderly people. This was the case of Dona Januária, for example, especially through the declarations of her 70-year old daughter who was her caregiver. As such the latter represented a clear example of the 'pivotal generation' (Delbes \& Gaymu 1993, Attias-Donfut 1995). She supported and took care of her centenarian mother, financially supported her unmarried 32-year old son, ("he got married before he was really able to") and paid the child support for her 5-year old grandson. After establishing a cordial relationship with the interviewer, she confided that she had some complaints about her mother, who was "very stubborn." There were the day-to-day frictions; Dona Januária's poor hearing created difficulties: "You say things once, she doesn't hear. You say them a second time, she still doesn't hear. You say them a third time and your voice already comes out a little different, right? When we speak more loudly, we speak in a strong voice, but then she says: 'That's just rude, you don't have to shout.' Then I say: 'But I'm not shouting, I'm just speaking louder."

She explained the care routine provided to her mother: "She needs me to give her a bath, I wash her, take her to the toilet, apply her makeup, wash her hands, and take her to the shower." But she also recognizes the effort made by her mother herself: "She also helps a lot, she has a lot of will power."

She thought that she did her best for her mother, though this was not always recognized: "I know that I do what I can, and sometimes even what I can't, but, I don't know, my sisters aren't always satisfied (...) a lot of advice, but help? There is none."

One time jealousy surfaced when she recounted that when her sister who lives in rural Bahia came to Salvador to stay in her house, the other sisters would complain. The sister would reply: "I came to stay with mum." "She stays here and plays guitar with her, because (Dona Januária) becomes animated and she is very lively too." She was also jealous of her son's relationship to his grandmother, another case of the classic understanding between alternate generations: "She likes him very much, he also likes her a lot; he seems to like her more than he likes me, it's 'granny' this, 'granny' that..."

Her son, Gustavo (32 years old) is a musician. He too spoke about Dona Januária: "My grandmother is great, an elderly persons but still strong, upright and everything." He explains that his interest in music came from her: "I would watch my grandmother with her guitar, playing those old songs, and I would sit there enchanted." He considered his grandmother "a young person. I think what keeps her young is the will to carry on living." 
The first reports that I received of Seu Bráulio referred to him as a poet and someone of very advanced age in equal measure. One of my interviewees (old but not a centenarian) insisted that I had to seek him out, speaking of him with admiration. However I only entered into contact after reading about him in a literary supplement in 2003. He was then 100 years old and in the process of publishing a book, Pentágono: Cinco Coroas de Sonetos. The launch at the João Fernandes da Cunha Foundation in Salvador was a festive occasion, accompanied by music and recitation of his poems. He was very happy and elegant attired in his suit.

Over the following years, I continued to accompany his family relations and literary career. As he began to publish less, a certain silence enveloped him in the press, indirectly broken a few times such as when they reported the death of the penultimate member of the literary group to which Seu Bráulio had belonged in his youth, the Poets of Baixinha. This report included the laconic reference: "...of which there now remains only Bráulio de Abreu, who is 103 years old" (Machado 2006). Direct contact was also maintained, including interviews with family members and periodic visits, which continued until a few months prior to his death.

In our first interview, Seu Bráulio made a point of observing that he had no health problems: "Not cholesterol, not my back, not diabetes. My blood pressure is 120/80." He fed himself and slept well, and added that "I feel good, I don't have any pains."

He was a widower and had five children (just one son). He lived with Eliana, his youngest daughter, also a widow, and her adolescent son. He missed his wife who had passed away ten years earlier and with whom he had enjoyed "a very calm life, we never had a row." He also told how he got along 'perfectly' with his daughter. She "takes care of the house and takes care of me, which isn't easy, taking care of a one hundredyear old elderly man.” They split the house expenses. Seu Bráulio, a former civil servant, received a pension worth a minimum wage. He was also assisted by his son who lived in another state. He talked about his financial difficulties, adding: "All I have is my poetry." Poetry was also his companion: "My pastime amounts to this, I spend my life here because my books are my life, it's what I read." He seldom went out, only when his children took him with them. "They don't want me to go out alone."

The daughter too great care of him: a regular diet and fixed meal times, he was not allowed to bathe alone in case he fell. He did everything that she ordered: "I obey her like an obedient boy." Smiling, Seu Bráulio assured us that he intended to live until he was 120: "I want to give my daughter lots of work taking care of me."

He received visits from relatives, friends and neighbors. The research team was not an exceptional case, therefore. He greeted everyone with courtesy. He was always in the bedroom, with his books and papers: "I write my poetry, because without it I can't live."

In an interview, the daughter with whom he lived said about him: "Though my father is an elderly person, he has kept up with the times. My father was never stuck in the past." She added, though, that he no longer took much part in the everyday family life: "His life is this, sat down all day, writing his poems..." But when get-togethers were held in the house where he lived, one of the other daughters described how "he would sit at the head of the table, he lunched with everyone (...) the party would end in poetry." Though Seu Bráulio described himself as the "dependent boss," as far as his young grandson, Eliana's son, was concerned, his grandfather was the head of the family: "Because he's the reason why the children are united. He's their point of reference (....) the one who manages to unite the family."

He described his loving relationship with his grandfather: "He likes me a lot, and I adore him. He demonstrates this affection in his own way, I show it in mine, but we always know how much we like each other." He compared his relationships with his grandfather and his mother: "[The latter] is a much more bossy relationship, while with my grandfather it's more about conversation. I disobey my mother but I don't disobey my grandfather." 
Our first contact with Dona Guiomar was in 2002 when she was 98 years old. Throughout the project we went back to her numerous times, and also interviewed most of her family. Despite various health problems - she used a pacemaker, walked with some difficulty due to a past accident, used a hearing aid, and was blind in one eye - she transmitted a remarkable energy and was very lively. She had an excellent memory and had a natural authority over the family.

A widow, she told us during the first interview that she had 7 children, 26 grandchildren and 42 greatgrandchildren. She had led an active professional life as secretary of an important educational institution, which she only left when she had to take compulsory retirement. She recounted how one employee from the institution had remarked: "But you're going to retire?!" "Still alive, like this? When your work is so perfect!" She replied: “I won't work for free for the government!" At the same time, she admitted: "How I miss it!"

All her dedication earned her just a small pension equivalent to the minimum wage. She lived in her own house, where she had been for more than 50 years, located in a poor district. She felt comfortable there and was visibly well-loved by her neighbors. A widowed daughter lived with her and maintained the house. A granddaughter, the daughter of this daughter, lived on the floor above with her husband and son.

Dona Guiomar told how up until a few years ago she had done everything around the home. She gradually stopped, "but I still work (...) I wash my own clothes." She liked to go for walks and visit restaurants with her children and grandchildren. She considered the relationship with her family "the best possible," which was indeed plain to see.

Concerning old age, she once remarked that "there are some elderly people who are abusive and others who are happy. I belong to the latter group, the happy old people, because I'm never in a bad mood..." She liked to listen to music and sing, and had played violin in the past. She told how every now and then she would sing in the backyard and was applauded by her neighbors.

She celebrated her centenary in 2004. The commemoration was held at a venue for big events with many generations present. The birthday girl, happy and smiling, sang while dancing with one of her sons, Aristóteles. As the only male child, he was an exception: he provided assistance to his mother constantly and visited her every day. She also danced with her doctor, who kissed her affectionately on the forehead. At the end of the party, she spoke using a microphone, thanking everyone, children, grandchildren, relatives and friends, for coming.

Talking about what she most wanted, she declared that: “I ask God that the days pass and he doesn't leave me bed-ridden, that he lets me stay on my feet until my time comes." A widespread concern of active older people everywhere, her wish was granted: she was able to move around and remained lucid until the end.

During our first interview, Dona Guiomar commented that perhaps the happiest period of her life had been this one, "because the children are already grown." Two years later her life became more difficult due to the serious health problems faced by two of her children. When she reached 102, in January 2006, she did not want a big celebration, which continued to be the case thereafter. Her oldest son, at the age of 78 , was hospitalized following a stroke, while the condition of her oldest daughter, who had Alzheimer's disease, became worse. In conversation, she confessed that: “I don't accept it, my dear. I just don't accept it. He is hospitalized at 78 years old. And myself, at this age, I am as good as new. In fact when I was 94 I used to say that I was 49." She also spoke about her ill daughter: “I keep imagining when I make 'my journey,' what will happen to Mercês? I still don't accept her situation. My oldest daughter... I always thought that she'd be taking care of me." 
Even in this situation, people visited her frequently and she received numerous telephone calls on her birthday. In subsequent visits by the research team, she again stated that she was very unhappy due to her children's health problems. "I'm afraid of 'going' and leaving Mercês all alone in this situation. She doesn't remember anything and sometimes only listens to me."

Soon after the aforementioned birthday, her son passed away. She oscillated between refusing to accept his death and feeling relieved, confiding that at least he was no longer suffering. It was the second son she had lost. "I'm 102 and I'm here, healthy! I'm only afraid of leaving my sick daughter behind, poor thing."

Dona Guiomar was in fact someone with a great presence, strong-minded and congenial. She was well-known and liked throughout the neighborhood. Despite her withdrawal from celebrations, she commemorated her $104^{\text {th }}$ birthday the following year in obligatorily happy style with a festive breakfast organized precisely by her neighbors.

Indeed this is one more fact reinforcing my observation of how the centenarians who I encountered have generally proven to be the object of considerable admiration and affection, even among those not involved in their immediate day-to-day life, like their neighbors. This affection and admiration is also strongly expressed in particular by the generation of grandchildren. This clearly occurred in the case of Dona Guiomar, as we also saw with Dona Januária and Seu Bráulio. In an interview, Cristina, 40 years old and granddaughter of Dona Guiomar, was speaking about being young when she curiously referred to her grandmother: "Being young is being open to things in the world, to people. I consider my grandmother to be someone with a young mind, she isn't shocked by anything, she welcomes everything new, she is a point of reference for young people. In terms of her mind, she is much younger than me, because I am very set in my ways."

Speaking later about the elderly, she returns, naturally enough, to her grandmother: "An elderly person like my grandmother is a great boon. Every time I go to see her, I come back refreshed because she tells me so many surprising things. She unites the family around her."

Dona Guiomar reached the age of 107 in January 2011 and once again was unable to evade the festive celebration. However, for the first time she spoke about death as a 'solution' for her and her daughter who was just resisting and surviving, though she did not fail to mention happy moments, like the beautiful party for her $100^{\text {th }}$ birthday: "It was some event!"

She began to complain about aches and started to avoid walking. She also began to have small episodes of forgetfulness - common enough to people of various ages, albeit not for her - like the time she invited one of the students from the research team for Sunday lunch the following month, but was surprised on the day to see her arrive. Nonetheless, she lucidly 'sorted out' the issue, telling her: "In my mind, I knew that I was forgetting something. I forget without forgetting." Afterwards, smiling, she repeated something that she always liked to do: she sang a song for the student that featured her name.

They ate the 'famous' bean stew that Miss Guiomar had already mentioned on various occasions as one of her favorite dishes. In typical Bahian fashion, this was accompanied by hot pepper sauce. She ate well and then went for a rest, not without singing again first, though. This time it was Mulheres, de Martinho da Vila, a samba that she particularly liked. She sang a few choruses and reaffirmed how much she enjoyed singing. It was the last time we would see her. The following month she died, 'still standing' and lucid, just as she had wanted and deserved. 


\section{Recognizing the vicissitudes}

The research continues alongside other projects. New centenarians have been discovered and the processes of being acquainted and developing relationships renewed. These four special personalities, however, remain strongly imprinted in our affective memory and admiration.

At the moment, I am working with centenarians who have spent less overall time with the project. I select some of them here, though, as they provide the opportunity to present a wider social context of life experiences, including two cases of families atypical in relation to earlier research findings. The title of the current project, Longevity and Generational Time, Ages and Vicissitudes, ${ }^{3}$ recognizes that new configurations are emerging in the lives of more elderly citizens and the centenarians are no exception. Though the family, in most cases, treats them well, providing care and affection, and are generally their main source of support, there is also some evidence that it is also within the family that elderly people often suffer more violence, both in day-to-day life and in their final days (Debert 2001, Faleiros 2007).

Given that the family comprises this variable terrain of affects, sometimes firm, at other moments shifting (Britto da Motta 2013), it is important to emphasize just how insecure life can become for the more elderly when they discover that there is no place of respite for them. Indeed it is in the public sphere that the greatest vicissitudes are manifested: the disqualifying competition when they are still in the labor market, but especially - and right until the end - the institutional neglect, various kinds of financial fraud, and the extra suffering caused by the absence of effective state policies (Britto da Motta 2013). And then there is the final devastating blow of abandonment, triggered by health issues and taking place mainly in hospitals, where elderly people often go to die (Souza, Meira \& Menezes 2012).

These are problems that only seem to be worsening today. Not just as a result of population growth, but especially because of the decline in solidarity and the increasing anomic ways of contemporary society. On one hand, further examples could be added to the felicitous stories of the centenarians analyzed above, like the current life experience of Dona Joana, aged 101. Robust and healthy, she enjoyed a lavish and joyous birthday party organized by her family, while her everyday life of regular domestic chores is assuaged both by the family's attempts to slow down her 'excess' of activities, as by the happy recitation of her numerous poems, which she also presents to her elderly group. Or the upbeat liveliness of Dona Benzinha, 95, who lives alone, but maintains strong connections with her family who live nearby and meet up with her every Monday. She is also a member of three different groups, paints tea-towels to sell and classifies herself as follows: "I'm at a rebellious age. I do whatever I want and think."

On the other hand, though, there are those who are 'family-less,' such as the previously mentioned Dona Eurides, 120. Widowed and childless, she was poorly looked after by the family member in whose house she had been staying, despite having her own financial resources. She became ill. After successful treatment, she was accepted as a resident in a healthcare institution, some 15 years ago. There she is very well treated and has developed close ties with her caregivers, or 'granddaughters' as she likes to call them.

The bitterest case is that of Dona Ana, a widow with four children, who received little attention or care and died one month ago. She was accompanied by our research team for almost two years, enough to discover that two birthdays went by with nobody from her family remembering the date. One of the students, attentive and already feeling affection for Dona Ana - who emphasized more than once that nobody had ever given her so much attention, not even her grandchildren or daughter, who was very silent - tried to organize a small celebration for her. Last year she took her a cake, but the daughter and son-in-law

3 Project "Longevity and Generational Time, Ages and Vicissitudes." Support CNPq (PQ Scholarship) PIBIC/FAPESB (IC Scholarship). Participation of students: Irani Santos Silva, Maiane Lima Santiago, Elideise Damasceno and Danielle Carla Correa de Pinho. 
with whom she lived went out to the supermarket... This year her birthday was again remembered by the student, but the daughter only remarked that she was embarrassed to having forgotten. Curiously, Dona Ana had remembered on both occasions - had she thought it pointless to mention her birthday to her family?

From time to time, Dona Ana complained of feeling unwell and tired, as well as pains, during the period that the research team accompanied her. There was no indication that she received medical care during this time. Once her condition worsened, she was hospitalized. However she did not seem to have received much professional attention, one family member complained. A few days later, she died.

\section{Conclusion}

Analyzing centenarians as a specific analytic category prompts a series of reflections, including:

On the social revolution that increasing longevity is creating, and the types of changes in social relations triggered by the simultaneous presence of multiple generations, both within the family and in the broader social context.

On the double nature of the category elderly: as a bundle of identities of a more general relational nature (of gender, class, race) and as an expanding generational/age sector, which the longer it extends, the more it is capable of giving rise to distinct temporal experiences that can become multiplied in 'generations.'

On the special 'something' that centenarians really possess (not necessarily 'secret' or 'mysterious') and that often distinguishes them even from their own 'third' and 'fourth' age children. Comparisons like those made by Dona Guiomar ("he is 78 , hospitalized; when I was the same age, I felt as good as new") and Seu Anísio ("the people said that he (the son) was older than me") aptly illustrate this point.

On the need to abandon any simplistic search for the cause (in the singular) along with the customary biological emphases common to geriatrics and gerontology, so as to be able to reflect instead on a confluence of different causes.

All of our subjects have presented, to a greater or lesser degree, the same beneficial socio-psychological characteristics, demonstrating the clear genetic advantage that they possess. As well as being essentially healthy, they are calm, sociable, happy, and interested in life. This is what makes them, even when they have some disability or medical problem, look beyond their complaints and declare that they have good health and wish to live longer.

Translated by Phillip Villani, revised by Cecilia Sardenberg and David Rodgers

Received 08/08/2015, approved 08/11/2015. 


\section{References}

ARIÈS, Philippe. 1983. "Une histoire de la vieillesse"? Communications, 37(1): 47-54.

ATTIAS-DONFUT, Claudine. 1995. « Le double circuit des transmissions”. In: (org.), Les solidarités entre générations. Paris: Nathan. pp. 41-81.

BEAUVOIR, Simone de. 1970. La vieillesse. Paris: Editions Gallimard.

BOURDIEU, Pierre. 1990. Coisas ditas. São Paulo: Brasiliense.

BRITTO DA MOTTA, Alda. 1998. "Reinventando fases: a família do idoso". In: (ed.), Dossiê: Gênero e família. Caderno $C R H, 29: 69-88$. . 1999. "As dimensões de gênero e classe social na análise do envelhecimento". Cadernos Pagu, 13:191221. . 2001. "Idosos na sociedade brasileira no limiar do século XXI". In: Vânia Gico; Antônio Spinelli; Pedro Vicente. (eds.). As Ciências Sociais - Desafios do Milênio. Natal: EDUFRN-PPGCS. pp.620-633. . 2003. "Espaço doméstico e gerações: disputas veladas e renúncias ambíguas". Anais do XI Encontro de Ciências Sociais do Norte e Nordeste. Aracaju, Universidade Federal de Sergipe, August 2003. Mimeo. . 2004. "Sociabilidades possíveis: idosos e tempo geracional". In: Clarice Ehlers Peixoto (org.),

Familia e envelhecimento. Rio de Janeiro: Fundação Getúlio Vargas. pp. 109-144. . 2006. “Ter cem anos no Brasil". Trabalho apresentado no $52^{\circ}$ Congresso Internacional de Americanistas, Sevilla. Mimeo. . 2010. "A família multigeracional e seus personagens". In: Kimi Tomizaki (ed.), Dossiê De uma

Geração a Outra. Educação e Sociedade, 31(111): 435-458. . 2012a. "Mulheres entre o cuidado dos velhos/as e a reprodução dos jovens em famílias no Brasil". Ex Aequo. Revista da Associação Portuguesa de Estudos sobre as Mulheres, 26: 87-101. . 2012b. "A juvenilização atual das idades". Caderno Espaço Feminino (Universidade Federal de

Uberlândia), 25: 36-42. . 2013. "Violências especificas aos idosos". Sinais Sociais, 8(22): 63-85.

CAMARANO, Ana Amélia. 1999. Muito além dos 6o. Rio de Janeiro: IPEA.

COMO passar dos 10o. Revista Época, São Paulo, ed. 408, seção sociedade, 9 March 2006. Source: <http:/|

g1.globo.com/bahia/noticia/2011/05/familia-de-idosa-baiana-reivindica-titulo-de-mulher-mais-velha-domundo.html>. Consulted: 6 May 2011.

DELBES, Christiane; GAYMU, Joelle. 1993. "Les families à quatre générations". Informations Sociales, 32 : 8-12. DEBERT, Guita Grin. 2001. "A família e as novas políticas sociais no contexto brasileiro". Interseçôes - Revista de Estudos Interdisciplinares, 3(2): 71-92.

FERNANDES, Ana Alexandre. 2001. "Velhice, solidariedades familiares e política social: itinerário de pesquisa em torno do aumento da esperança de vida". Sociologia, 36: 39-52.

FALEIROS, Vicente de Paula. 2007. Violência contra a pessoa idosa - ocorrências, vítimas e agressores. Brasília: Universa.

Ibahia-Com cento e vinte anos. Soteropolitana, pode ser a mulher mais velha do mundo. Source: www.ibahia.com. Consulted: 7 April 2015.

LENOIR, Remi. 1979. "L'invention du troisième age: constitution du champ des agents de gestion de la vieillesse". Actes de la Recherche en Sciences Sociales, 26: 57-84.

LINS DE BARROS, Myriam. 2006. “Gênero, cidade e geração: perspectivas femininas”. In: (ed.),

Familia e gerações. Rio de Janeiro: Fundação Getúlio Vargas. pp. 19-37.

MACHADO, Luiza. 2006. "Saudades da Baixinha”. A Tarde, Salvador, Suplemento Cultural, 29 April 2006. 
MANNHEIM, Karl. 1928. “O problema das gerações”. In: Sociologia do conhecimento. Porto, PT: Res Editora. pp.115-176.

OLIVEIRA, Flávio. 2002. "Baiana pode ser mulher mais velha do mundo". A Tarde, Salvador, 5 June 2002. PEIXOTO, Clarice Ehlers. 2004. "Aposentadoria: retorno ao trabalho e solidariedade familiar". In:

(ed.), Familia e envelhecimento. Rio de Janeiro: Fundação Getúlio Vargas. pp. 57-84.

SOUZA, Carolina Marback Barbosa. 2009. O trabalho dos aposentados em Salvador-Bahia: interfaces entre mercado, previdência e familia. Tese de Doutorado em Ciências Sociais - Faculdade de Filosofia e Ciências Humanas, Universidade Federal da Bahia, Salvador.

SOUZA, Andréa dos Santos; MEIRA, Edméia Campos; MENEZES, Maria do Rosário de. 2012. "Violência contra pessoas idosas promovida em instituição de saúde". Mediações, 17(2): 57-72.

\section{Alda Britto da Motta}

Department of Sociology, Faculty of Philosophy and Human Sciences, Federal University of Bahia, Salvador/BA, Brazil

aldamottao1@hotmail.com 